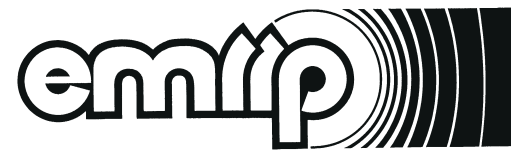

\title{
Management of Bottomland Hardwood Forests for Nongame Bird Communities on Corps of Engineers Projects
}

PURPOSE: This technical note is a product of the Ecosystem Management and Restoration Research Program (EMRRP) work unit titled "Improved Methods for Ecosystem-Based Habitat Management at Corps Projects." The objective of the work unit is to provide appropriate technology on managing wildlife species and their habitats using ecosystem-based strategies. The emphasis is on methods that improve natural resources for a variety of animals rather than single species. Bottomland hardwoods represent an important natural resource associated with stream and river floodplains throughout the Southeastern United States. These forest systems support a complex array of plant and animal species that are uniquely adapted to flood conditions and alternating dry periods. Moreover, these habitats often support a higher diversity of avifauna than adjoining upland habitat and may act as sources for bird populations, which permits the maintenance of regional diversity in highly fragmented landscapes. Corps projects are often associated with lakeshores, rivers, and streams; thus, there are many opportunities to identify and manage large areas of bottomland systems on Corps lands in the Southeast.

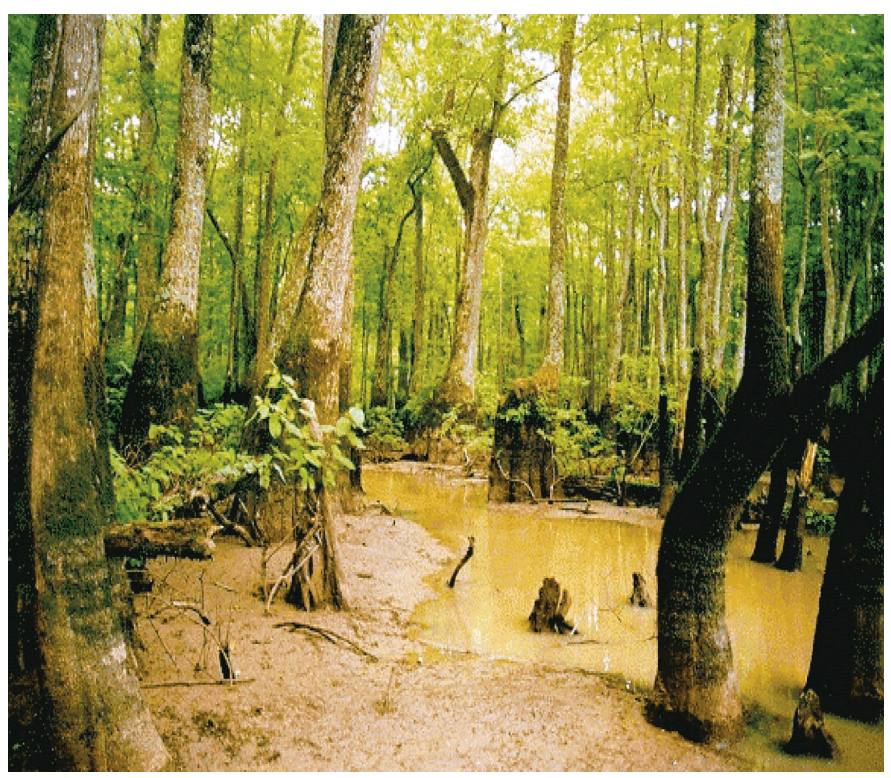

Figure 1. A bottomland hardwood forest dominated by swamp tupelo and bald cypress

BACKGROUND: The U.S. Army Corps of Engineers (Corps) has constructed over 450 reservoir projects in the continental United States. These projects encompass approximately 12 million acres (4.8 million ha) of land and water habitat under Corps management (Fischer and Hamilton 1999). In the Southeastern United States, the Corps manages about 90 reservoir projects, including over 60 projects within the known distribution of bottomland hardwoods (Figure 2). Although land holdings under Corps management are small relative to lands managed by the U.S. Forest Service or National Park Service, Corps lands are located along primary migration routes for many landbird species (Fischer and Hamilton 1999) and may provide important breeding habitat in landscapes highly fragmented by agricultural lands in the Mississippi Alluvial Valley (MAV).

Bottomland hardwood forests vary from mixed hardwood forests along stream basins to deepwater swamps along major rivers and coastal estuaries. These systems perform numerous important ecological functions which include acting as sources of aquifer recharge, capturing and dispersing sedimentation, filtering agricultural runoff, and minimizing flood damage by holding 


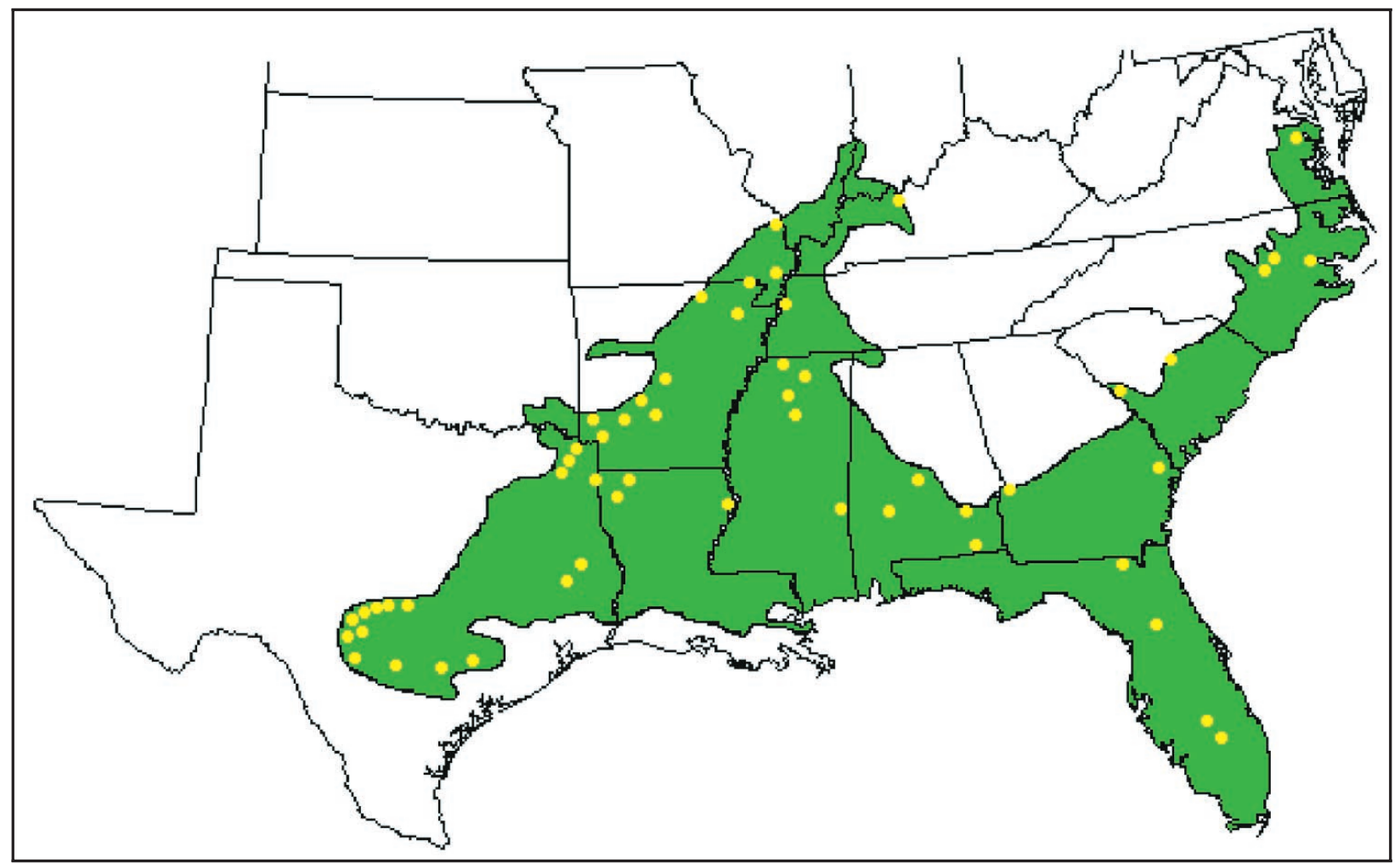

Figure 2. Distribution of bottomland hardwoods with bald cypress (from Mitsch and Gosselink (1993)) and Corps reservoir projects (from Fischer and Hamilton (1999)) in the Southeastern United States

vast amounts of water (Brinson 1990; Taylor, Cardamone, and Mitsch 1990; Fischer et al. 1999). Hence, bottomland systems are critical in purifying and maintaining water quality. This role serves to improve habitat quality far beyond the extent of bottomland systems (e.g., serving as sources of animal and plant dispersal) (Fischer et al. 1999). Because bottomland forests often comprise the largest forest tracts in agricultural and urban settings, these habitats are critically important as refugia for area-sensitive species both locally and regionally. Approximately 30 percent of threatened and endangered species in the Southeast depend on bottomland hardwoods during some portion of the year (Brinson et al. 1981, Ernst and Brown 1989), and about 85 percent of eastern North American bird species utilize bottomland forests in the MAV (Smith, Hamel, and Ford 1993); approximately 70 bird species breed in these habitats (Pashley and Barrow 1992).

Often, economic benefits of agriculture, urban expansion, and other human land uses override the need for the ecological benefits provided by bottomland forests; thus, these systems are often targeted for land use conversion. An estimated 21 to 25 million acres (8.4 to 10 million ha) of bottomland forests once existed in the MAV (Mitsch and Gosselink 1993). Approximately 80 percent of bottomland hardwood systems have been lost, with most losses occurring in the 20th century. The MAV has experienced the most severe losses, with agricultural conversion accounting for approximately 96 percent of the bottomland hardwood forests lost (Stanturf et al. 2000). Currently, existing area of bottomland forest systems is estimated between 7 and 12.3 million acres (2.8 and 4.9 million ha) in the MAV (King and Keeland 1999, Stanturf et al. 2000). 
CHARACTERISTICS OF BOTTOMLAND HARDWOOD FORESTS: River hydrology and inundating flood events create features that are unique to bottomland systems including natural levees, sloughs, meander scrolls, and oxbow lakes (Taylor, Cardamone, and Mitsch 1990; Pashley and Barrow 1992). Woody plant species in these habitats often have morphological and/or physiological features that permit growth and reproduction in anaerobic soil conditions (Huffman and Forsythe 1981; Taylor, Caradamone, and Mitsch 1990). Geomorphological and hydrological features of bottomland forests define characteristics of the system through erosion and deposition of sediments by the water flow. These features, in turn, define the characteristics of the hydroperiod. Seasonal timing, frequency, duration, and depth of flood events are ultimate features of the hydroperiod that determine plant community composition and dynamics (Lugo, Brinson, and Brown 1990). Other factors influencing the hydroperiod include climate, topography, channel slope, groundwater storage capabilities, and regional geology (Wharton et al. 1982, Fischer et al. 1999). Several aspects of the geomorphology of the floodplain have important impacts on the flooding regime and the structure of the system. One aspect is the velocity and volume of water movement, which affects the slope, bank geometry, natural levee formation, and degree of erosion and deposition of nutrients (Sharitz and Mitsch 1993). Another aspect is the size of the watershed or catchment size. Larger catchment floodplains tend to have longer and deeper flood events; therefore, catchment size is often the most important characteristic determining hydrology (Brinson 1990).

In bottomland hardwood systems, plant communities tend to segregate along the elevation gradient from the open water of the river or stream to the nonflooded transitional areas. Using this natural separation, Larson et al. (1981) devised a classification of floodplain forests based on the zonation of plant communities and their location along the hydrologic gradient. Six zones are typically used to describe floodplain forests (Figure 3). Roughly (from Wharton et al. 1982),

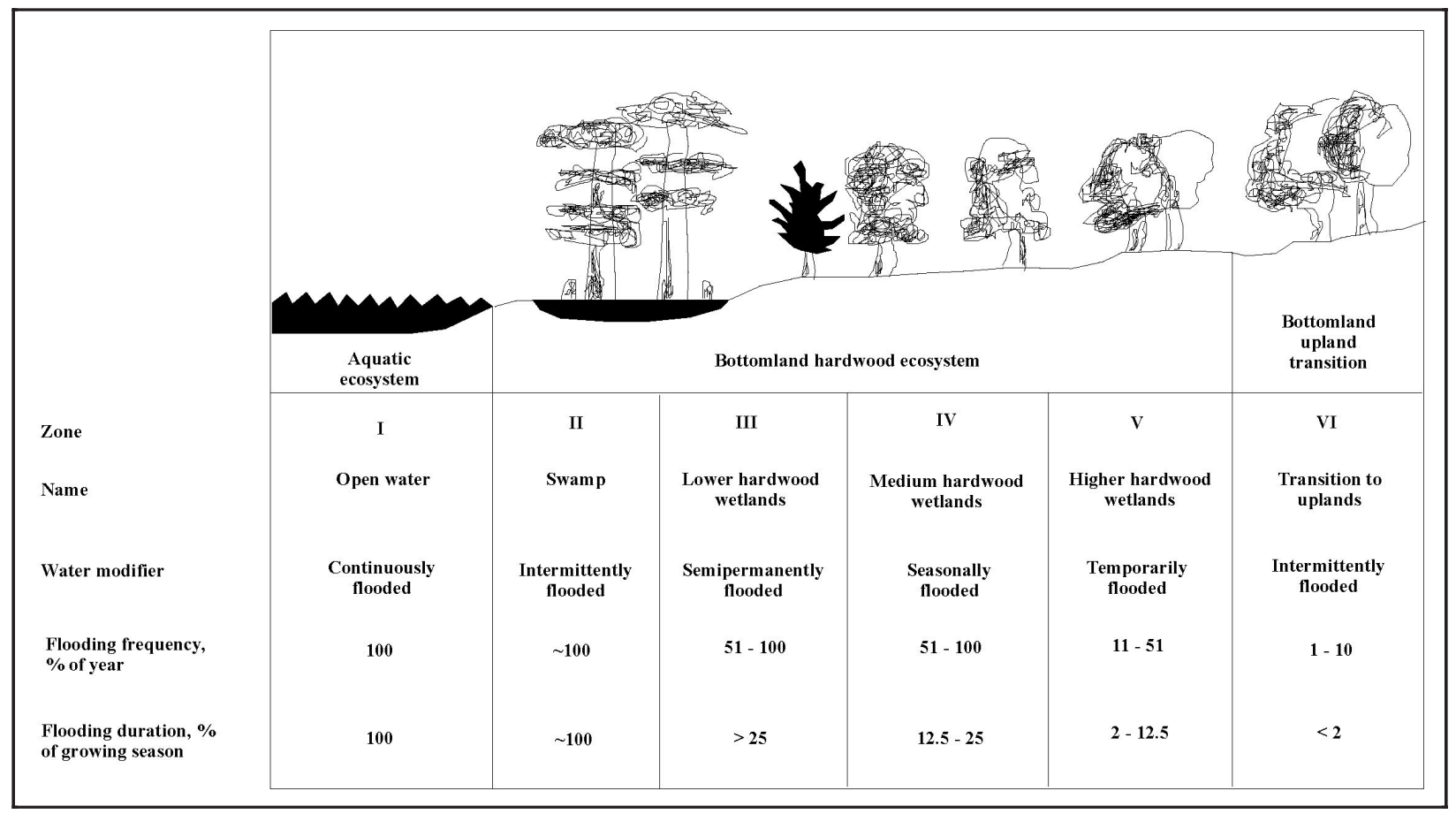

Figure 3. Classification zones of bottomland hardwoods in the southeastern United States (from Clark and Benforado 1981) 
zone I refers to river channels, oxbow lakes, and permanently inundated backsloughs; zones IIIII refer to cypress swamps and swales; zone IV refers to flats and backswamps; zone V refers to levees, relict levees and terraces, and zone VI refers to the floodplain-upland transitional area that links bottomlands to terrestrial ecosystems. While this classification may be an oversimplification of bottomland systems, it has been found to be useful in describing most forested wetlands in the Southeast and provides an important tool in establishing management guidelines locally and regionally (Wharton et al. 1982). Moreover, since bird communities inhabiting bottomland hardwoods are also influenced by the hydrological gradient (Wakeley and Roberts 1996), hydrologic zones are useful in understanding bird/plant community relationships.

\section{IMPORTANCE OF BOTTOMLAND HARDWOODS TO BIRD COMMUNITIES: Avian}

use of southern bottomland hardwoods differs seasonally (Guilfoyle, Moorman, and Kilgo 2001) and can be influenced by fluctuating water levels (Kushlan 1989). These wetlands provide important breeding habitat for Neotropical migrants, ${ }^{1}$ wintering nearctic migrants, 2 and yearround residents. ${ }^{3}$ High water levels may provide high quality habitat for wintering waterfowl, yet diminish habitat suitability for numerous woodpeckers and other woodland species. During periods of low water levels, bottomland hardwoods may be utilized by several wading birds, including the great blue heron (Ardea herodias) and the white ibis (Eudocimus albus), and acorncaching species, such as the redheaded woodpecker (Melanerpes erythrocephalus). Bottomland systems also once supported several species now believed to be extinct, including the ivorybilled woodpecker (Campephilus principalis) and Bachman's warbler (Vermivora bachmanii). The following provides a summary of the seasonal importance of bottomland hardwoods to avian communities.

Migrating birds. Every fall and spring, tens of millions of migrant birds fly across the Gulf of Mexico. During the fall, coastal habitats along the Gulf are the last available stopover areas before the long trans-Gulf flight, and during the spring, coastal areas are the first habitats encountered by arriving migrants (Moore et al. 1995). Expanses of bottomland hardwoods along the coasts of Louisiana and Mississippi are part of the MAV and are known to constitute important stopover habitats for migrants, particularly during the spring. Monitoring of spring migrants using WSR-88D doppler radar along the Gulf Coast has shown that migrants frequently land in bottomland forests along river systems upon arrival and depart these areas during early morning hours (Gauthreaux 1999). Often, migrating birds will fly over coastal areas and land inland along forested river systems. Large river systems may be used by migrants as large-scale landmarks that help orient birds during passage to the breeding grounds (Gill 1990). If birds are using river systems as landmarks, then associated forested habitats along rivers may be vital for a successful migration for many species. Extensive loss of bottomland forests and other stopover habitats may significantly increase mortality for many species during the costly process of

1 Neotropical migrant bird species breed in North America but migrate to wintering grounds in Mexico, Central and South America, and the Caribbean Islands.

2 Nearctic migrants (also called temperate migrants) reside in North America year-round yet typically breed in the northern United States and Canada, and winter in the southern portions of the United States.

3 Resident species are typically nonmigratory species that breed and winter in the same general geographical area. 
migration; hence, lack of available high-quality stopover habitat may be a factor contributing to the reported decline of numerous Neotropical migrant species nationally (Moore et al. 1995). Examples of species found during migration in bottomland forests include black-throated blue warblers (Dendroica caerulescens) (Figure 4), American redstarts (Setophaga ruticilla) (Figure 5), Baltimore orioles (Icterus galbula), and black-throated green warblers (Dendroica virens).

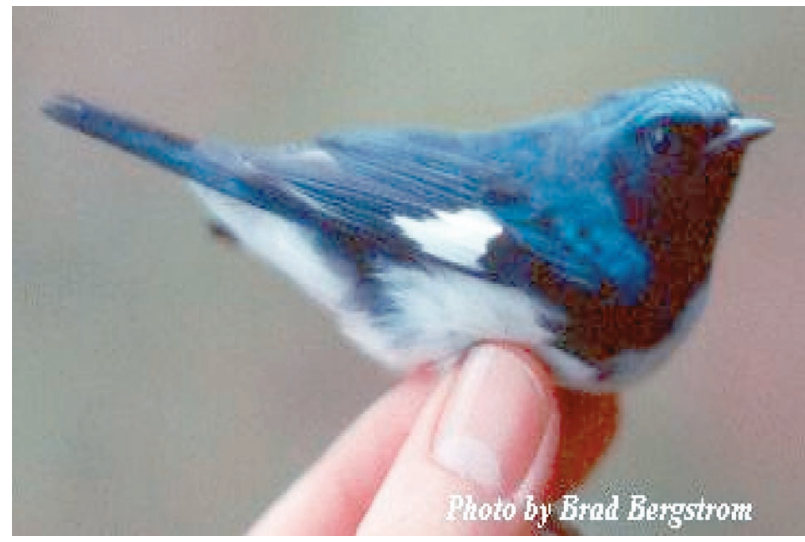

Figure 4. The black-throated blue warbler (Dendroica caerulescens), a relatively common migrant in southern bottomland hardwoods

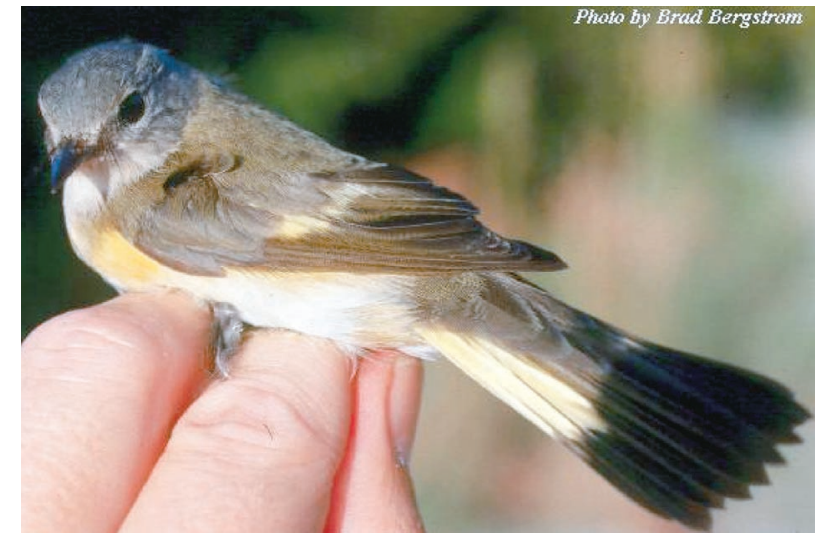

Figure 5. The American redstart (Setophaga ruticilla), a common migrant and potential breeder in southern bottomland hardwoods

Wintering birds. Southern bottomland hardwoods support a diverse array of nearctic migrants and year-round resident birds during the winter months. Nearctic migrants in southern bottomlands account for about 55 percent of the bird community, while residents and occasional transient species comprise the rest of the community (Dickson 1978). Typical nearctic species in southern bottomland hardwoods include the ruby-crowned kinglet (Regulus satrapa), yellowrumped warbler (Dendroica coronata), white-throated sparrow (Zonotrichia albicollis), brown creeper (Certhia americana), and yellow-bellied sapsucker (Sphyrapicus varius) (Figure 6). During high water levels, bottomland hardwoods may also support many wintering waterfowl species, including the wood duck (Aix sponsa), mallard (Anas platyrhynchos), and hooded merganser (Lophodytes cucullatus). Many winter species are very mobile and move sporadically during the season, complicating habitat models and showing few correlations with vegetation structure (Ford 1990). Flocking behavior, particularly among gregarious birds such as the common grackle (Quiscalus quiscula), white-throated sparrow (Zonotrichia albicollis), and American crow (Corvus brachyrhynchos), appear stochastic in nature, yet reflect the process of searching for available food sources (Dickson 1978; Erlich, Dobkin, and Wheye 1988). Some species that focus on specific food types, such as the red-headed woodpecker (Figure 7), may remain locally during the season, but may not be present in subsequent years, or may move during periods of high water levels (Smith, Withgott, and Rodewald 2000). Other species maintain territories during the winter months, or at least remain in a locally defined area. These species may focus on specific habitat attributes, particularly dense vegetative growth that may occur along edges or tree-fall canopy gaps (Guilfoyle, Moorman, and Kilgo 2001). 


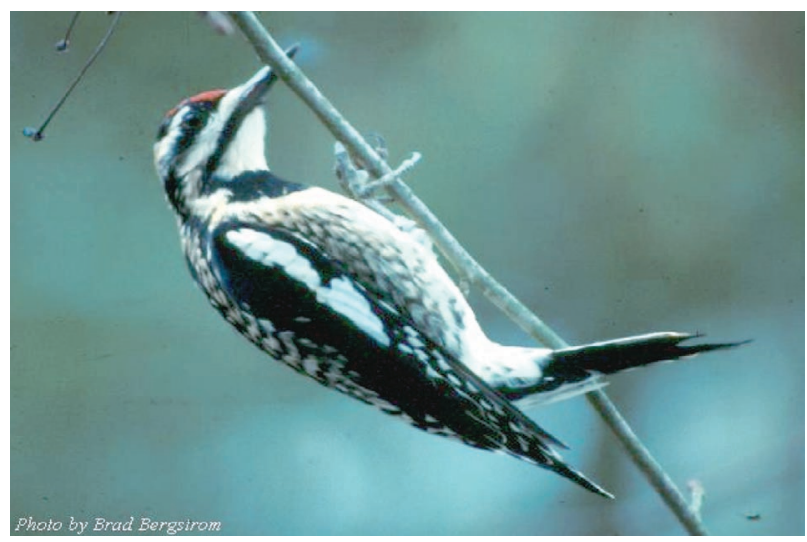

Figure 6. The yellow-bellied sapsucker (Sphyrapicus varius) is a wintering species in southern bottomland hardwoods

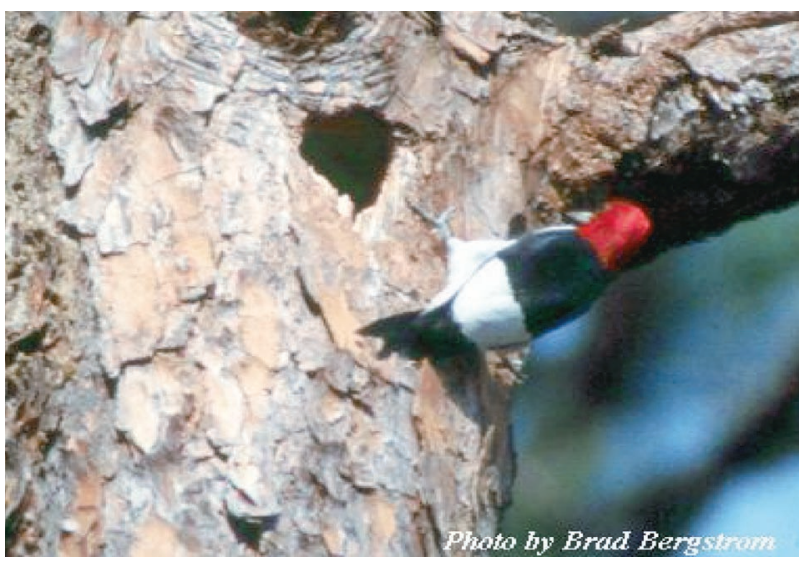

Figure 7. The red-headed woodpecker (Melanerpes erythrocephalus) is a locally common wintering species and an uncommon breeding species in southern bottomland

Resident birds. Numerous species are year-round residents in bottomland hardwoods. Generally, year-round resident species comprise about 35 to 55 percent of seasonal bird communities (Dickson 1978, Zeller and Collazo 1995). Some species, such as the White-breasted Nuthatch (Sitta carolinensis) (Figure 8), will maintain a defended territory year-round, although juveniles may move considerably during the winter (Pravosudov and Grubb 1993). The Pileated Woodpecker (Dryocopus pileatus) is the largest North American woodpecker, and remains largely in bottomland habitat in the Southeast. Other woodpeckers, including the Downy Woodpecker (Picoides pubescens) (Figure 9) and Red-bellied Woodpecker (Melanerpes carolinus), are also common bottomland residents. Examples of other common residents include the Tufted Titmouse (Baeolophus bicolor), Carolina Wren (Thryothorus ludovicianus) and Carolina Chickadee (Poecile carolinensis). Several wading birds may also be year-round residents in bottomland forests, particularly along the Gulf of Mexico and in Florida. Examples include the Great Blue Heron, Great Egret (Ardea alba), and Yellow-crowned Night Heron (Nyctanassa violacea).

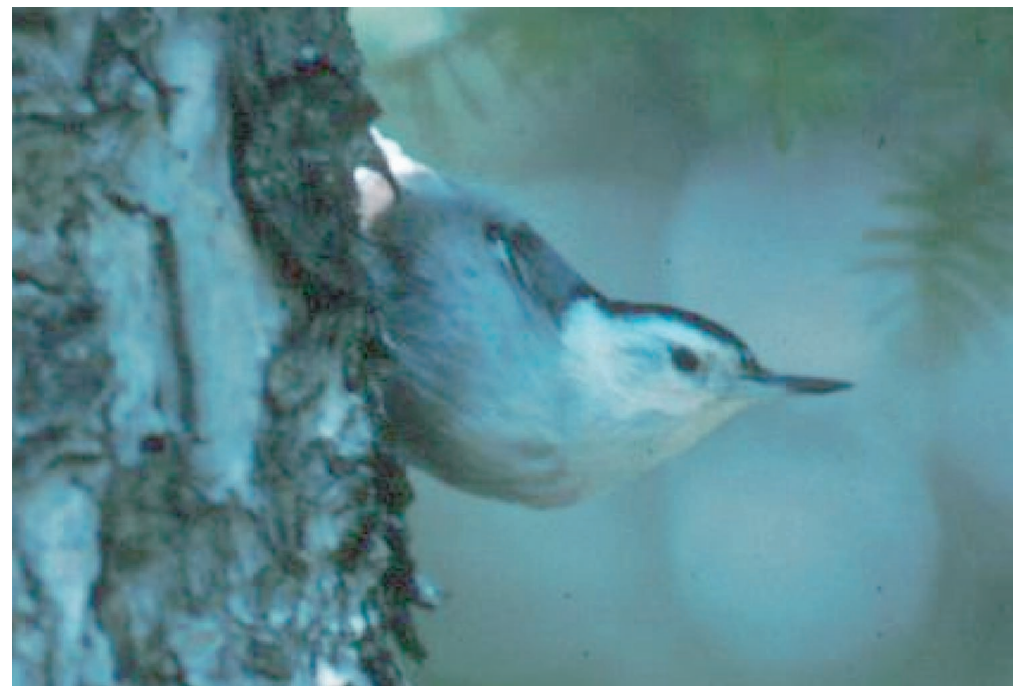

Figure 8. The white-breasted nuthatch (Sitta carolinensis) is a year-round resident in southern bottomland hardwood forests
Breeding birds. Southern bottomland hardwoods are renowned for supporting large numbers of breeding bird species. During the breeding season, the number of Neotropical migrants breeding in these habitats ranges from 48 to 65 percent of the total breeding bird assemblage (Pashley and Barrow 1992). While many resident and wintering species are found in a variety of forested habitats, many breeding species either breed exclusively in bottomland forests or have highest densities and/or reproductive success in 
these areas. Several species are considered forested wetland specialists, including the prothonotary warbler (Protonotaria citrea) (Figure 10) and the swallow-tailed kite (Elanoides forficatus) (Meyer 1995, Petit 1999). One of the most common Neotropical migrants, the acadian flycatcher (Empidonax virescens) (Figure 11), is largely restricted to forested wetland habitats during the breeding season in the Southeast. An endangered species, the wood stork (Mycteria americana), is a wading bird that breeds specifically in forested habitats and mangroves throughout the Southeast. Although not generally considered a Neotropical migrant, this species roams widely during the nonbreeding season, and its range extends into Central America and the Caribbean Islands (Coulter et al. 1999). A species of warbler showing sharp declines dur-

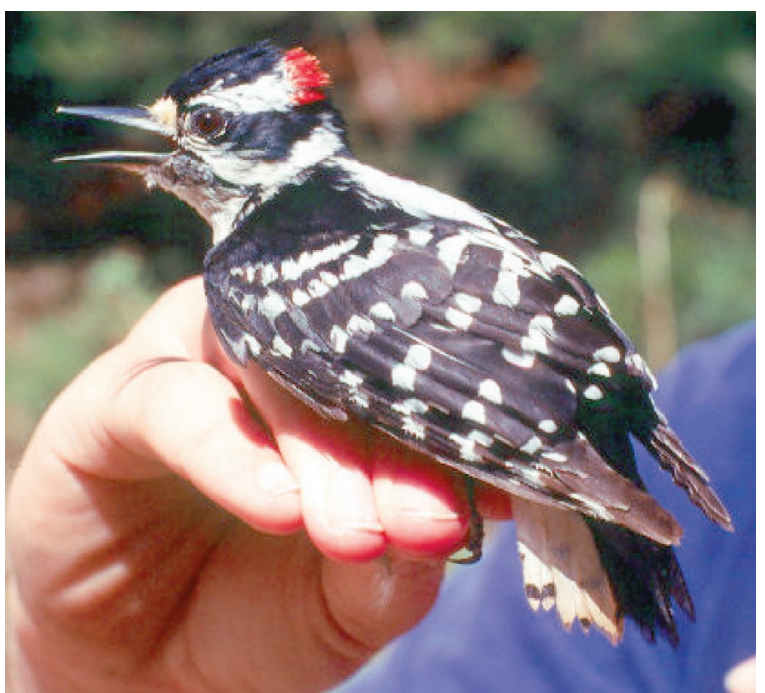

Figure 9. The Downy Woodpecker (Picoides pubescens) is a relatively common year-round resident in southern bottomland hardwood forests ing the past few decades is the Cerulean Warbler (Dendroica cerulea). This warbler achieves highest densities and reproductive success in bottomland forests in the Southeast. Habitat loss through fragmentation and degradation of bottomland systems has contributed to declines for all these species.

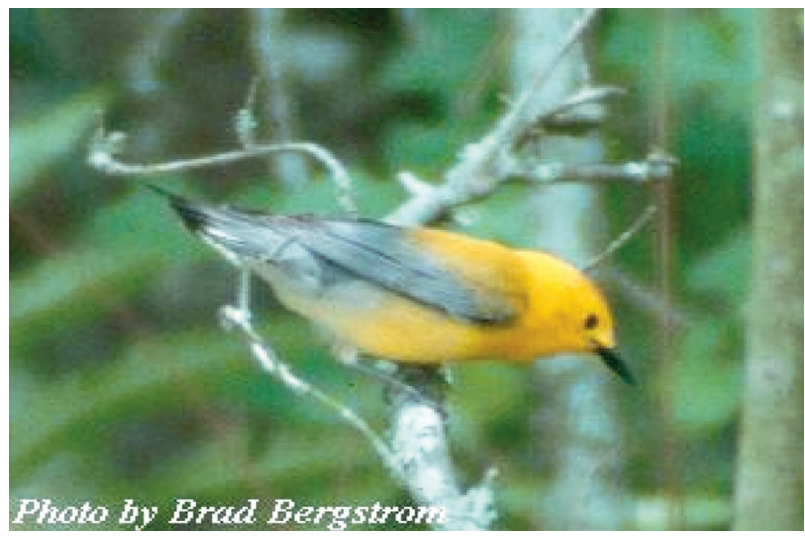

Figure 10. The prothonotary warbler (Protonotaria citrea) is a declining cavity nesting bird in bottomland hardwoods

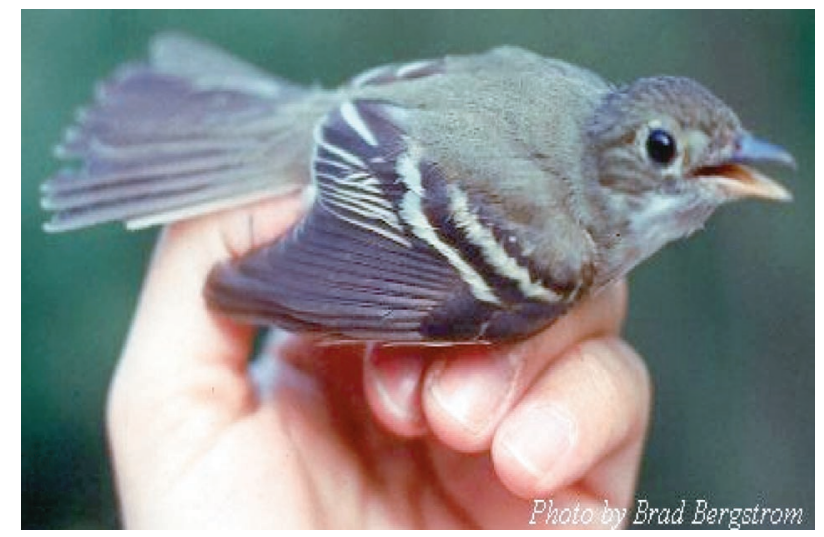

Figure 11. The acadian flycatcher (Empidonax virens), is a relatively common breeding bird in bottomland hardwoods

Several structural features of bottomland hardwoods affect use by breeding Neotropical species. Since hydrology strongly influences structural habitat features within these systems, perhaps it is not surprising that bird community composition varies within the different plant community zones identified by Larson et al. (1981) (see Figure 3) (Wakeley and Roberts 1996). Zones I and II, reflecting open water and bald cypress (Taxodium distichum) swamps, are characterized by the presence of the chimney swift (Chaetura pelagica), yellow-throated warbler (Dendroica dominica), and northern parula (Parula americana) (Barrow 1990). Chimney swifts forage over the open water, while yellow-throated warblers forage among the bald cypress foliage for insects 
(Barrow 1990). Northern parulas often nest around bald cypress stands and are correlated with the presence of Spanish moss (Tillandsia usneoides) that is frequently used as nesting material (Barrow 1990, Pashley and Barrow 1992). Seasonally flooded areas representing zones III and IV are often characterized by the presence of five species, the eastern wood-pewee (Contopus virens), great-crested flycatcher (Myiarchus crinitus), yellow-throated vireo (Vireo flavifrons), blue-gray gnatcatcher (Polioptila californica), and prothonotary warbler (Pashley and Barrow 1992). These zones may also have patches of switchcane (Arundinaria gigantea) thickets. These canebrakes are used by numerous species including the swainson's warbler (Limnothlypis

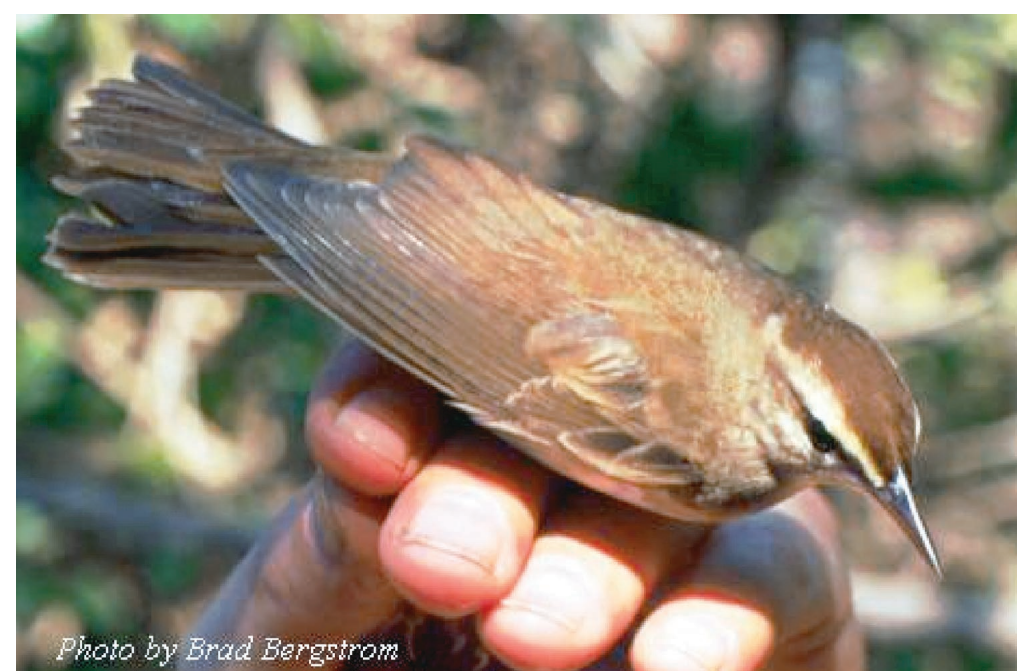

Figure 12. The Swainson's warbler (Limnthypis swainsonii), a high priority species listed by Partners in Flight in most of the southern physiographic regions swainonnii) (Figure 12), hooded warbler (Wilsonia citrina) and the white-eyed vireo (Vireo griseus). Also in these zones, primarily in the lower reaches of the MAV, palmetto (Sabal minor) may be a prime component of swainson's warbler habitat. The transitional areas between bottomland hardwoods and upland habitats, comprising zones V and VI, are often characterized by the presence of the red-eyed vireo (Vireo olivaceus), American redstart (Setophaga ruticilla), swainson's warbler, and hooded warbler (Pashley and Barrow 1992).

PARTNERS IN FLIGHT: Long-term declines for many nongame bird populations throughout North America inspired the formation of an international cooperative organization involving government agencies, conservation groups, private industry, philanthropic foundations, universities, and individuals to acquire information, conduct research, and develop strategies to halt the population declines. This organization, Partners in Flight (PIF), has focused efforts on identifying specific species and habitats most in need of conservation (Fischer and Hamilton 2001). Approximately 60 physiographic regions were identified within the continental United States based on classification of habitat types and associated plant communities. Within each region, known bird species were identified and assigned a prioritization score according to their conservation needs. Focus was placed on species known to breed within each physiographic region, yet the prioritization process also includes information on nonbreeding biology (Carter et al. 2000, Fischer and Hamilton 2001). A high overall (global) priority score is a species scoring 22 or higher in the PIF prioritization formula. Such a high score reflects a species whose populations are vulnerable throughout the species ranges, irrespective of the species-specific status in a given physiographic region. A species with a high physiographic area priority typically scores between 19 and 21, and reflects a species with moderately high global vulnerability whose population is declining, or is of uncertain status within the physiographic area (Fischer and Hamilton 2001). 
Within the southeastern United States, ten primary physiographic regions reflect the extent of bottomland hardwood distribution (see Table 1; Figures 2 and 13). These regions include Subtropical Florida (01), Peninsular Florida (02), South Atlantic Coastal Plain (03), East Gulf Coastal Plain (04), Mississippi Alluvial Valley (05), Coastal Prairies (06), Interior Low Plateaus (14), Ozarks and Ouachitas (19), West Gulf Coastal Plain (42), and the Mid-Atlantic Coastal Plain (44) (Table 1; Figure 13) (PIF 2001). Another physiographic region, the Oaks and Prairies region (08) lies within the range of bottomland hardwoods in central Texas. However, this region does not list bottomland hardwood systems or associated bird species as a conservation priority (PIF 2001). Partners in Flight has listed bottomland hardwoods or forested wetlands as priority habitat in the 10 primary physiographic regions shown in Figure 13. One exception is Subtropical Florida, where mangrove swamps are the primary type of forested wetland. Within the bottomland hardwood or forested wetland habitat types, all eight of these physiographic areas share several priority bird species in common (Table 1). The most frequently listed species include the swallow-tailed kite, Swainson's warbler, prothonotary warbler, and cerulean warbler. Other species of concern include the Kentucky warbler (Oporornis formosus), yellow-billed cuckoo (Coccyzus americanus), wood thrush (Hylocichla mustelina), and the worm-eating warbler (Helmintheros vermivorus) (Table 1).

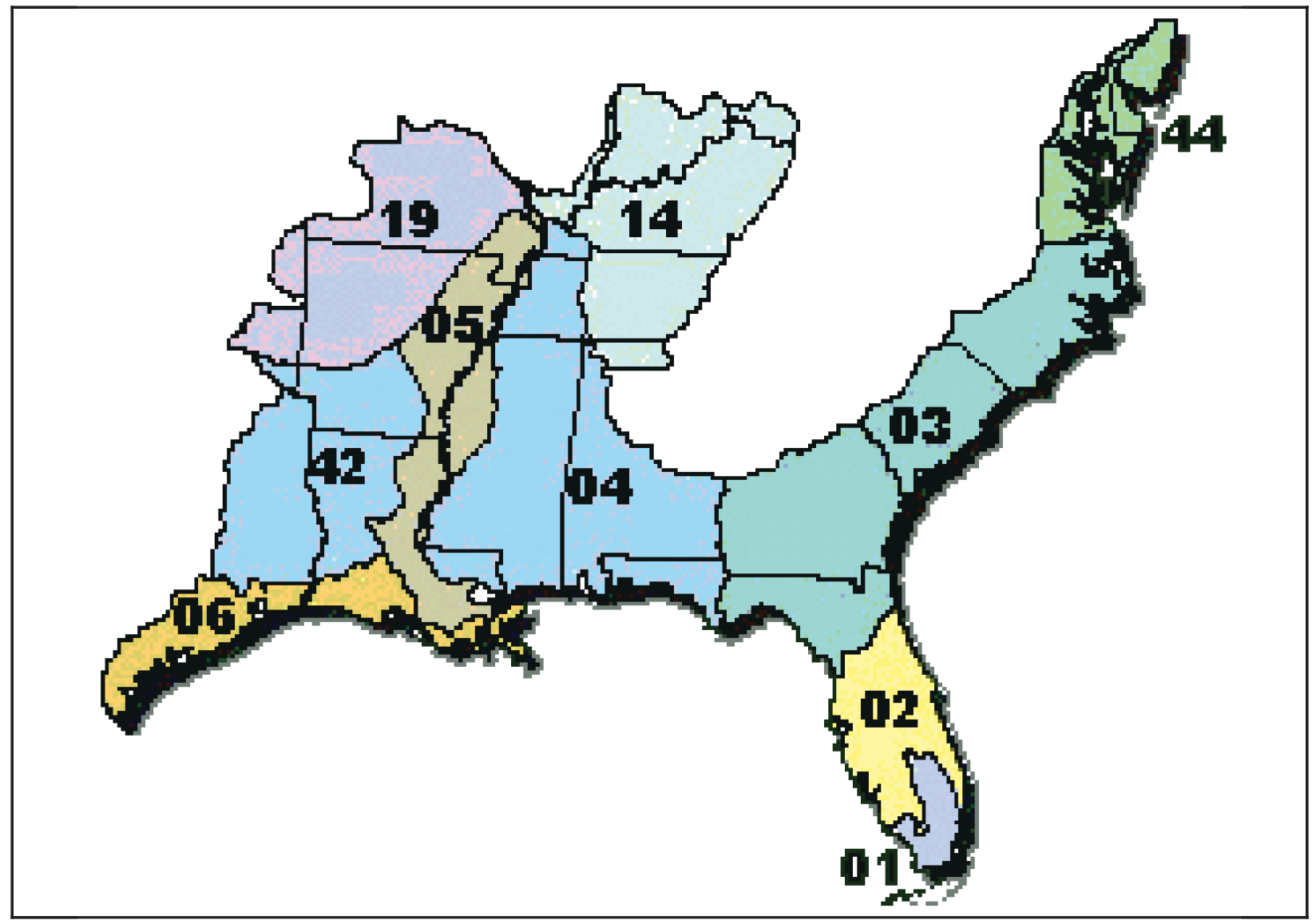

Figure 4. Map showing the 10 primary physiographic regions in the Southeast identified by Partners in Flight that list bottomland hardwood systems and associated bird species as a conservation priority 


\begin{tabular}{|c|c|c|c|c|c|c|c|c|c|c|}
\hline PIF Priority Species & $\begin{array}{l}\text { Subtropical } \\
\text { Florida (01) } \\
\end{array}$ & $\begin{array}{l}\text { Peninsular } \\
\text { Florida (02) } \\
\end{array}$ & $\begin{array}{l}\text { South } \\
\text { Atlantic } \\
\text { Coastal } \\
\text { Plain (03) }\end{array}$ & $\begin{array}{l}\text { East Gulf } \\
\text { Coastal } \\
\text { Plain (04) }\end{array}$ & $\begin{array}{l}\text { Mississippi } \\
\text { Alluvial } \\
\text { Valley (05) } \\
\end{array}$ & $\begin{array}{l}\text { Coastal } \\
\text { Prairies } \\
\text { (06) }\end{array}$ & $\begin{array}{l}\text { Interior } \\
\text { Low } \\
\text { Plateaus } \\
\text { (18) }\end{array}$ & $\begin{array}{l}\text { Ozarks } \\
\text { and } \\
\text { Ouachitas } \\
\text { (19) }\end{array}$ & $\begin{array}{l}\text { West Gulf } \\
\text { Coastal } \\
\text { Plain (42) }\end{array}$ & $\begin{array}{l}\text { Mid-Atlantic } \\
\text { Coastal } \\
\text { Plain (44) }\end{array}$ \\
\hline Acadian Flycatcher & & & & & & & $\mathrm{X}$ & $\mathrm{x}$ & & \\
\hline American Redstart & & & & & & & $x$ & & & \\
\hline $\begin{array}{l}\text { Black-throated Green } \\
\text { Warbler }^{2}\end{array}$ & & & $x$ & & & & & & & \\
\hline Blue-gray Gnatcatcher & & & & & $\mathrm{x}$ & & & & & \\
\hline Carolina Chickadee & & & & & $x$ & & & $\mathrm{x}$ & & $\mathrm{x}$ \\
\hline Cerulean Warbler & & & $\mathrm{x}$ & $\mathrm{x}$ & $x$ & & $\mathrm{x}$ & $x$ & $\mathrm{x}$ & $x$ \\
\hline Chimney Swift & & & & $x$ & & & & & & $x$ \\
\hline $\begin{array}{l}\text { Great-crested } \\
\text { Flycatcher }\end{array}$ & & & & & & & & $x$ & & \\
\hline Hooded Warbler & & & $\mathrm{x}$ & & & & & & $\mathrm{x}$ & \\
\hline Kentucky Warbler & & & & $\mathrm{x}$ & $\mathrm{x}$ & & & $\mathrm{x}$ & $x$ & $\mathrm{x}$ \\
\hline Louisiana Waterthrush & & & & & & & & $\mathrm{x}$ & $\mathrm{x}$ & \\
\hline Northern Parula & & & $\mathrm{x}$ & & $\mathrm{x}$ & & $\mathrm{x}$ & & & \\
\hline Ovenbird & & & & & & & & $\mathrm{x}$ & & \\
\hline Pileated Woodpecker & & & & & & & & $\mathrm{x}$ & & \\
\hline Prothonotary Warbler & & & $\mathrm{x}$ & $\mathrm{x}$ & $\mathrm{x}$ & $\mathrm{x}$ & $\mathrm{x}$ & $\mathrm{x}$ & $\mathrm{x}$ & $\mathrm{x}$ \\
\hline $\begin{array}{l}\text { Red-headed } \\
\text { Woodpecker }\end{array}$ & & & & $x$ & $x$ & & & & $x$ & \\
\hline $\begin{array}{l}\text { Ruby-throated } \\
\text { Hummingbird }\end{array}$ & & & & & $\mathrm{x}$ & & & & & \\
\hline Scarlet Tanager & & & & & & & & & & $\mathrm{x}$ \\
\hline Summer Tanager & & & $\mathrm{x}$ & & & & & $\mathrm{x}$ & & \\
\hline Swainson's Warbler & & & $x$ & $x$ & $x$ & $x$ & $x$ & $x$ & $x$ & $x$ \\
\hline Swallow-tailed Kite & $\mathrm{x}$ & $\mathrm{x}$ & $\mathrm{x}$ & $\mathrm{x}$ & $\mathrm{x}$ & $\mathrm{x}$ & & & $\mathrm{x}$ & \\
\hline Yellow-billed Cuckoo & & & $x$ & $x$ & $x$ & & & $\mathrm{x}$ & $\mathrm{x}$ & \\
\hline Yellow-throated Vireo & & & $\mathrm{x}$ & & & & & & & $\mathrm{X}$ \\
\hline $\begin{array}{l}\text { Yellow-throated } \\
\text { Warbler }\end{array}$ & & & & & & & $x$ & $x$ & & \\
\hline Wood Thrush & & & $x$ & & $x$ & & $\mathrm{X}$ & & & $x$ \\
\hline Worm-eating Warbler & & & $\mathrm{X}$ & $\mathrm{X}$ & $\mathrm{x}$ & & & $\mathrm{x}$ & $\mathrm{x}$ & $\mathrm{x}$ \\
\hline
\end{tabular}

RESTORATION OF BOTTOMLAND HARDWOOD FORESTS: Large-scale losses of bottomland hardwoods, along with the realization of the important functions provided by these habitats, have fueled initiatives to restore forested bottomlands throughout the Southeast (King and Keeland 1999, Stanturf et al. 2000). Restoration of bottomland hardwood habitats has been implemented by numerous federal agencies, including the U.S. Fish and Wildlife Service, U.S. Army Corps of Engineers, and the USDA Natural Resource Conservation Service, and numerous state agencies. Also, the USDA Wetland Reserve Program (WRP) has been successful in providing funds and tax incentives to promote restoration on private lands. In the MAV, approximately 78,000 acres (31,000 ha) have been replanted during the past 10 years, and over 100,000 acres (40,000 ha) have been proposed for restoration during the next decade (Allen 1997, King and Keeland 1999). Nationally, over 1 million acres (400,000 ha) are enrolled in the WRP in the Southeast, and approximately 60 percent of wetland restoration is for forested wetland habitats 
(King and Keeland 1999). Economic demand for hardwood fiber products may stimulate further restoration efforts in the MAV. Nearly 3 million acres (1.2 million ha) of marginal farmland in the MAV could potentially be reforested if proper economic and financial conditions prevail (King and Keeland 1999). Additionally, recent concern over eutrophication of the Mississippi River and the potential negative impact of agricultural runoff on coastal fisheries operations may increase demand for restoration of forested wetlands throughout the MAV (Rabalais et al. 1996, King and Keeland 1999).

Despite the positive prognoses for bottomland restoration efforts, considerable work is still needed. For example, little or no standardization exists to assess the success of restoration efforts. Without clear guidelines of desirable objectives for bottomland hardwood restoration, it is impossible to evaluate when a bottomland forest has been successfully restored. Currently, most restored bottomland areas are less than 20 years old. Evaluations of success have varied greatly. With some evaluation methods, restoration efforts are considered successful even with an 80-percent mortality rate for planted seedlings. Moreover, evaluation of restoration success or failure rarely extends beyond 5 years after initial planting efforts (King and Keeland 1999). Structural and functional properties of bottomland systems likely require a minimum of 60 years to reach maturity, and probably longer to achieve conditions necessary to benefit wildlife populations (Twedt and Portwood 1997, Wigley and Lancia 1998, King and Keeland 1999). Although restored stands of bottomland hardwoods are beneficial to wildlife, it is unlikely that currently restored areas reflect the structure and function of the original forests. Furthermore, current restoration efforts are insufficient to offset continued regional losses (King and Keeland 1999). Restoration efforts must be dramatically increased to compensate for continued loss and degradation of these forested wetlands, while time and research are still needed to develop criteria and guidelines for restoration efforts.

High mortality of planted seedlings necessitates considerable planning before planting efforts are initiated. Hydrology, soil types, and topography of an area must be accounted for before planting takes place. Most restoration efforts focus on numerous species of oak (Quercus spp.) during restoration. Oaks are generally preferred because of the known benefits of mast-producing species to numerous wildlife game species and wintering waterfowl, and the economic demand for oak timber. However, oak species may vary greatly in tolerance to flooding regimes and may show considerable variability between regions (Theriot 1993). Using acorns or oak seedlings from nearby sources may be necessary to achieve a high survival rate; however, obtaining suitable seeds and seedlings is often difficult. A recent survey found that many restoration efforts have had difficulty acquiring high quality seeds and seedlings (King and Keeland 1999). Almost all planted seedlings, including oaks and other tree species, experience high mortality from numerous herbivores such as white-tailed deer (Odocoileus virginianus), beaver (Castor canadensis), and nutria (Myocastor coypus). If fast-growing species are planted, more intensive weed control is required during the first few years after planting (Twedt and Portwood 1999), but seedling success is much higher than for oak seedlings. While use of oaks may be important for many game species and timber products, nongame birds probably benefit from bottomland forests with high vertical vegetative structure, regardless of tree species composition. Fast-growing tree species including cottonwood (Populus deltoides) and sycamore (Platanus occidentalis) are often colonized quickly by Neotropical migrant species (Twedt and Portwood 1999), and therefore should be considered in the management and restoration of bottomland hardwoods for nongame birds. 
MANAGEMENT ISSUES: Corps projects in the Southeastern United States have the potential to manage numerous bottomland hardwood forest tracts and to take a proactive role in bottomland hardwood restoration efforts. Moreover, the Corps has the authority to grant or deny permits for activities that may destroy or impact forested wetlands adjacent to navigable water resources. The Corps is taking the initiative in restoring numerous tracts of bottomland hardwood forests, particularly in the MAV (King and Keeland 1999), but efforts are less intensive than those of other federal and state agencies. Issues of water quality and wildlife resources, particularly nongame birds, are good incentives to take the lead in managing and restoring bottomland hardwoods (Fischer and Hamilton 2001).

The ability of Corps personnel to manage and restore bottomland hardwoods would be aided by efforts to address and research the following topics:

- Identify the extent of bottomland hardwood forests currently existing on Corps projects.

- Assess the ability to restore bottomland forests throughout the Southeast and MAV.

- Determine the best tree species composition for restoring forests for birds and water quality concerns.

- Identify structural and functional goals for restored bottomland systems.

- Characterize habitat features important to wintering, migrating, and breeding birds.

- Determine impacts of project construction and operation on forest bird composition and the overall quality of bottomland forest tracts.

- Develop guidelines for bottomland forest management and restoration in coordination with other federal and state agencies.

Numerous efforts to protect, promote, and initiate bottomland hardwood restoration are already in place; the Corps only has to take a more proactive role. The number and extent of Corps projects throughout the Southeast justify playing a greater role in bottomland hardwood restoration. By coordinating efforts with PIF and the WRP, the location and extent of bottomland management and restoration can be made to meet the needs of nongame birds and other economic and sociological concerns.

MANAGEMENT RECOMMENDATIONS: The following are recommendations for managing and restoring bottomland hardwood forest for nongame bird communities. These recommendations are based on the PIF management plan in the MAV (Twedt et al. 1999), and from Twedt and Portwood (1997) and Mueller, Twedt, and Loesch (2001).

- Identify and protect existing stands of bottomland hardwood forests. Since most remaining forest tracts are imbedded in an agricultural landscape, even small tracts may be useful to numerous bird species, especially during migration.

- Identify and monitor bottomland stands where PIF priority bird species are breeding. Establish a monitoring protocol that can detect presence/absence of priority bird species. A standardized protocol using point-count surveys has been developed for the Southeast by Hamel et al. (1996). 
- Assess quality of existing bottomland forests as wintering and migratory stopover habitat for nongame birds. Quality of existing forests may be indexed by quantifying bird abundance and bird species diversity during spring and fall migration and the wintering season. Since migration during the spring and fall often occurs over a period of several months, survey efforts should attempt to measure abundance and diversity repeatedly. Peak migration during the spring generally begins in mid-April and extends through late May, while peak migration during the fall begins in late August and extends through mid-October. Survey efforts can be accomplished using point surveys during the wintering and migration seasons, yet efforts can be modified to survey different suites of species. For example, boat surveys and aerial surveys may be suitable for waterfowl and shorebirds. Often, during periods of high flood levels in the winter, even point-count surveys may have to be done by boat or canoe.

- Identify areas that may be suited to restoration efforts; coordinate restoration plans with long-term plans for forested wetland conservation goals stated in the Bird Conservation Plans within the respective Southeastern PIF physiographic regions. Reforestation efforts should focus on increasing the size of small tracts and linking forest tracts together when possible.

- Establish clear goals and conditions for the reestablishment of bottomland hardwood forests and monitor success of restoration efforts; devise a standard protocol for monitoring efforts and coordinate efforts with other restoration projects in the physiographic area; monitor success of restoration efforts over time for as long as funding permits. Goals for restoration should reflect a combination of factors including the survival of planted tree species, formation of vegetated understory, colonization of reforested areas by various bird and other animal species, and the restoration of hydrologic functions. Specific restoration goals may require a case-by-case evaluation, yet overall assessment of restoration success should be based on guidelines established through coordinated restoration efforts with other federal and state agencies.

- Plant a combination of oak and fast-growing hardwood species during the restoration effort. Establishing stands of fast-growing tree species will promote rapid colonization by numerous bird species, and likely other wildlife species as well.

- Harvest merchantable timber as single tree or group tree cuts to mimic levels of natural disturbance. Small forest tracts within the MAV are likely imbedded in a landscape of agriculture lands; therefore, these tracts should be protected and efforts made to prevent further degradation of the habitat. Since timber harvesting may degrade small forest tracts for numerous sensitive bird species, harvesting should be limited to only large tracts of bottomland forest (e.g., $\geq 250$ acres or 100 ha).

- If possible, attempt to reestablish hydrologic functions in any restored bottomland; dependency of numerous tree species on frequent flood events may limit restoration success ifflooding regimes are not restored. Aspects of hydrology central to wetland functions in bottomland systems may be managed by controlling beavers, constructing levees, reestablishing trees in moist soil units, and potentially utilizing water control structures as tools to create hydrologic regimes that mimic natural conditions (King and Keeland 1999). In some situations, levees may need to be removed in order to reestablish overbank flood events. Careful planning will be needed to avoid potential conflicts in reestablishing flood regimes that may affect agricultural and urban areas. 
SUMMARY: Bottomland hardwood forests support diverse plant and wildlife communities uniquely adapted to inundating water levels. These forests were once the dominant forest type in the southeastern United States, but during the past century, these habitats have suffered extensive losses due to increased demand for agricultural products and expanding urbanization. Channelization of river systems also alters the hydrology of existing bottomlands and diminishes the ability of these systems to filter nutrient loads, thus potentially impacting numerous wildlife species. Bottomland forests are important to numerous nongame bird species. The association of these forests with rivers and streams makes them particularly important for migratory birds, but these areas also support diverse breeding and wintering bird communities. During the breeding season, bottomland forests may be vital breeding areas for several declining species of neotropical migrants and other PIF priority bird species.

The Corps operates 60 projects throughout the Southeast and thus has an opportunity to play an important role in the management and restoration of bottomland forests. The Corps is already involved in restoration efforts, but the extent of these efforts is limited. The important role the Corps plays in managing river systems, including implementation of the Clean Water Act for the protection and mitigation of wetlands via the issuing of permits, necessitates that the Corps take a proactive role in the management and restoration of bottomland systems. In this capacity, the Corps also plays an important role in conservation efforts for nongame birds. Understanding the importance of bottomland systems to seasonal bird communities, the distribution and abundance of bird species on Corps lands, the extent to which birds will colonize restoration sites, and the placement of restored areas in the landscape are all issues that need to be addressed. The Corps also needs to coordinate restoration efforts with other federal and state agencies to establish clear goals and specific guidelines for establishing successful restoration of bottomland hardwood systems.

POINTS OF CONTACT: For additional information, contact Mr. Michael P. Guilfoyle (601634-3432, michael.p.guilfoyle@erdc.usace.army.mil), the work unit coordinator, Mr. Chester O. Martin (601-634-3958, chester.o.martin@erdc.usace.army.mil), or the Manager of the Ecosystem Management and Restoration Research Program, Dr. Russell F. Theriot (601-634-2733, russell.f.theriot@erdc.usace.army.mil). This technical note should be cited as follows:

Guilfoyle, M. P. (2001). "Management of bottomland hardwood forests for non-game bird communities on Corps of Engineers projects," EMRRP Technical Notes Collection (ERDC TN-EMRRP-SI-21), U.S. Army Engineer Research and Development Center, Vicksburg, MS. www.wes.army.mil/el/emrrp

ACKNOWLEDGMENTS: This technical note was reviewed by Mr. Chester O. Martin and Drs. Richard A. Fischer and Wilma Mitchell. Photo Credits are provided below.

\section{PHOTO CREDITS}

Bottomland Hardwood (Figure 1). Photo and all copyrights belong to Michael P. Guilfoyle. Permission to use photo by Mr. Guilfoyle.michael.p.guilfoyle@erdc.usace.army.mil

Bird Pictures (Figures 4 - 12). All bird photos and copyrights belong to Dr. Bradley J. Bergstrom. Permission to use photos given by Dr. Bergstrom (7/27/2001). http://www.valdosta.edu/ bergstrm 


\section{REFERENCES}

Alerstam, T. (1990). "Bird migration," Cambridge University Press, New York.

Allen, J. A. (1997). "Reforestation of bottomland hardwoods and the issue of woody species diversity," Restoration Ecology 5, 25-134.

Barrow, W. C., Jr. (1990). "Ecology of small insectivorous birds in a bottomland hardwood forest," Ph.D dissertation, Louisiana State University, Baton Rouge.

Brinson, M. M. (1990). "Riverine forests," Ecosystems of the world: Forested Wetlands. A. E. Lugo, M. M. Brinson, and S. Brown, ed., Vol. 15, Elsevier Science Publishing, Co., NY, 87-141.

Brinson, M. M., Swift, B. L., Plantico, R. C., and Barclay, J. S. (1981). "Riparian ecosystems: Their ecology and status," U.S. Fish and Wildlife Service, Biological Services Program, FWS/OBS-81/17, Washington, DC.

Carter, M. F., Hunter, W. C., Pashley, D. N., and Rosenburg, K. V. (2000). "Setting conservation priorities for landbirds in the United States: The Partners In Flight approach," Auk 117, 541-548.

Clark, J. R., and Benforado, J., eds. (1981). "Wetlands of bottomland hardwood forests," Elsevier, Amsterdam.

Coulter, M. C., Rodgers, J. A., Ogden, J. C., and Depkin, F. C. (1999). "Wood stork (Mycteria americana).” The Birds of North America. A. Poole and F. Gill, ed., No. 409, The Birds of North America, Inc., Philadelphia, PA.

Dickson, J. G. (1978). "Seasonal bird populations in a south central Louisiana bottomland hardwood forest," Journal of Wildlife Management 42, 875-883.

Erlich, P. R., Dobkin, D. S., and Wheye, D. (1988). “The birder's handbook: A field guide to the natural history of North American birds," Simon \& Schuster Inc., New York.

Ernst, J. P., and Brown, V. (1989). "Conserving endangered species on southern forested wetlands." Proceedings of the symposium: The forested wetlands of the southern United States. D. D. Hook and R. Lea, ed., GTR-SE-50. USDA Forest Service, Southeastern Forest Experiment Station, Asheville, NC, 135-145.

Fischer, R. A., and Hamilton, H. R. (1999). "Esprit de Corps: Land and water for neotropical migratory birds," Bird Conservation, Special Issue, 18.

Fischer, R. A., and Hamilton, H. R. (2001). "The Importance of Corps of Engineers lands to migrating and breeding birds," EMRRP Technical Notes Collection (ERDC TN-EMRRP-SI-20), U.S. Army Engineer Research and Development Center, Vicksburg, MS. www.wes.army.mil/el/emrrp

Fischer, R. A., Martin, C. O., Robertson, K., Whitworth, W. R., and Harper, M. G. (1999). "Management of bottomland hardwoods and deepwater swamps for threatened and endangered species," Technical Report SERDP-99-5, U.S. Army Engineer Research and Development Center, Vicksburg, MS.

Ford, R. P. (1990). "Habitat relationships of breeding birds and winter birds in forested wetlands of west Tennessee," Master's thesis, The University of Tennessee, Knoxville.

Gauthreaux, S. A., Jr. (1999). "Monitoring bird migrations and movements with radar and Landsat Imagery-II," Interim Technical Report, Legacy Project, No. 991872.

Guilfoyle, M. P., Moorman, C. E., and Kilgo, J. C. (2001). "Seasonal relationships between avian community metrics and canopy gaps in southeastern bottomland hardwood forests." Ecology and management of bottomland hardwood systems: The state of our understanding. L. Fredrickson, R. Kaminski, and S. King, ed., Symposium Proceedings, March 10-13, 1999, Memphis, TN.

Hamel, P. H., Smith, W. P., Twedt, D. J., Woehr, J. R., Morris, E., Hamilton, R. B., and Cooper, R. J. (1996). “A land manager's guide to point counts of birds in the Southeast," General Technical Report SO-120, U.S. Department of Agriculture, Forest Service, Southern Research Station, Asheville, NC.

Huffman, R. T., and Forsythe, S. W. (1981). "Bottomland hardwood forest communities and their relation to anaerobic soil conditions." Wetlands of bottomland hardwood forests. J. R. Clark and J. Benforado, ed., Elsevier, Amsterdam, 177-185. 
King, S. L., and Keeland, B. D. (1999). "Evaluation of reforestation in the lower Mississippi River alluvial valley," Restoration Ecology 7, 384-359.

Kuslan, J. A. (1989). “Avian use of fluctuating wetlands.” Freshwater wetlands and wildlife. R. R. Sharitz and J. W. Gibbons, ed., DOE Symposium Series, No. 61, USDOE Office of Scientific and Technical Information, Oak Ridge, TN, 593-604.

Larson, J. S., Bedinger, M. S., Bryan, C. F., Brown, S., Hoffman, R. T., Miller, E. L., Rhodes, D. G., and Touchet, B. A. (1981). "Transition from wetlands to uplands in southeastern bottomland hardwood forests." Wetlands of bottomland hardwood forests, J. R. Clark and J. Benforado, ed., Elsevier, Amsterdam, 225-273.

Lugo, A. E., Brinson, M., and Brown, S., ed. (1990). Ecosystems of the world: Forested wetlands. Vol. 15. ElsevierScience Publishing Co., New York.

Meyer, K. D. (1995). "Swallow-tailed Kite (Elanoides forficatus)," The Birds of North America. A. Poole and F. Gill, ed., No. 138, The Birds of North America, Inc., Philadelphia, PA.

Mitsch, W. J., and Gosselink, J. G. (1993). Wetlands, 2nd Edition. Van Nostrand Reinhold, New York.

Moore, F. R., Gauthreaux, S. A., Jr., Kerlinger, P., and Simons, T. R. (1995). "Habitat requirements during migration: Important link in conservation." Ecology and management of neotropical migratory birds. T. E. Martin and D. M. Finch, ed., Oxford University Press, New York, 121-144.

Mueller, A. J., Twedt, D. J., and Loesch, C. R. (2001). "Development of management objective for breeding birds in the Mississippi Alluvial Valley." Strategies for bird conservation: The Partners In Flight planning process. R. Bonney, D. N. Pashley, R. J. Cooper, and L. Niles, ed., Cornell Laboratory of Ornithology, Ithica, NY. http://birds.cornell.edu/pifcapemay/ (20 April 2001).

Partners In Flight. (2001). "Partners In Flight: Physiographic areas plans," http://www.blm.gov/wildlife/pifplans.htm (16 March 2001).

Pashley, P. N., and Barrow, W. C. (1992). "Effects of land use practices on neotropical migratory birds in bottomland hardwood forests." Status and management of neotropical migratory birds. D. M. Finch and P. W. Stangel, ed., General Technical Report RM-229. U.S. Department of Agriculture, Forest Service, Fort Collins, CO, 315-320.

Petit, L. J. (1999). "Prothonotary warbler (Protonotaria citrea).” The Birds of North America. A. Poole and F. Gill, ed., No. 409, The Birds of North America, Inc., Philadelphia, PA.

Pravosudov, V. V., and Grubb, T. C., Jr. (1993). "White-breasted nuthatch (Sitta carolinensis)." The Birds of North America. A. Poole and F. Gill, ed., No. 54, The Birds of North America, Inc., Philadelphia, PA.

Rabalais, N. N., Turner, R. E., Justic, D., Dortch, Q., Wiseman, W. J., Jr., and Sen Gupta, B. K. (1996). "Nutrient changes in the Mississippi River and system responses on the adjacent continental shelf," Estuaries 19(2b), 386-407.

Sharitz, R. R., and Mitsch, W. J. (1993). "Southern floodplain forests.” Biodiversity of the Southeastern United States: Lowland terrestrial communities. W. H. Martin, S. G. Boyce, and A. C. Echternacht, ed., Wiley \& Sons, Inc., New York, 311-371.

Smith, K. G., Withgott, J. H., and Rodewald, P. G. (2000). "Red-headed woodpecker (Melanerpes erythrocephalus)." The Birds of North America. A. Poole and F. Gill, ed., No. 518, The Birds of North America, Inc., Philadelphia, PA.

Smith, W. P., Hamel, P. B., and Ford, R. P. (1993). "Mississippi alluvial valley forest conversion: Implications for eastern North American avifauna." Proceedings of the Annual Conference of Southeastern Association of Fish and Game Agencies 47, 460-469.

Stanturf, J. A., Gardiner, E. S., Hamel, P. B., Devall, M. S., Leininger, and Warren, M. E., Jr. (2000). "Restoring bottomland hardwood ecosystems in the lower Mississippi Alluvial Valley," Journal of Forestry, August, 10-16.

Taylor, J. R., Cardamone, M. A., and Mitsch, W. J. (1990). "Bottomland hardwood forests: Their functions and values." Ecological processes and cumulative impacts: Illustrated by bottomland hardwood wetland ecosystems. J. G. Gosselink, L. C. Lee, and T. A. Muir, ed., Lewis Publishing, Inc., Chelsea, MI, 13-86. 
Theriot, R. F. (1993). "Flood tolerance of plant species in bottomland forests of the southeastern United States," Technical Report WRP-DE-6, U.S. Army Engineer Waterways Experiment Station, Vicksburg, MS.

Twedt, D. J., Pashley, X. X., Hunter, C., Mueller, A., Brown, C., and Ford, B. (1999). "Mississippi Alluvial Valley (Physiographic Area \#05)," Partners In Flight, Bird Conservation Plan.

Twedt, D. J., and Portwood, J. (1997). "Bottomland hardwood reforestation for neotropical birds: Are we missing the forest for the trees?" Wildlife Society Bulletin 25, 647-652.

Wakeley, J. S., and Roberts, T. H. (1996). "Bird distributions and forest zonation in a bottomland hardwood wetland," Wetlands 16, 296-308.

Wharton, C. H., Kitchens, W. M., Pendleton, E. C., and Sipe, T. W. (1982). "The ecology of bottomland hardwood swamps of the Southeast: A community profile," U.S. Fish and Wildlife Service, Biological Services Program, Washington, DC. FWS/OBS-81/37.

Wigley, T. B., and Lancia, R. A. (1998). "Wildlife communities." Southern forested wetlands: Ecology and Management. M. G. Messina and W. H. Conner, ed., Lewis Publishers, Boca Raton, FL, 205-236.

Zeller, N. S., and Collazo, J. A. (1995). "Abundance and distribution of overwintering passerines in bottomland hardwood forests in North Carolina," Wilson Bulletin 107, 698-708. 